\title{
A TRACER STUDY OF BATANGAS STATE UNIVERSITY (BATSTATEU)- LIPA CITY GRADUATES OF SY 2017 - 2018
}

\author{
Dr. Nerrie E. Malaluan ${ }^{1} 凹$, Dr. Michael C. Godoy ${ }^{1}$, Dr. Francis G. Balazon ${ }^{1}$, Monette \\ M. Soquiat ${ }^{1,}$ Ma. Lourdes Balita ${ }^{1}$ \\ ${ }^{* 1}$ Batangas State University- Lipa City, Philippines
}

DOI: https://doi.org/10.29121/granthaalayah.v8.i6.2020.396

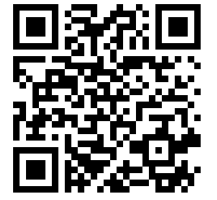

Article Type: Case Study

Article Citation: Dr. Nerrie E. Malaluan, Dr. Michael C. Godoy, Dr. Francis G. Balazon, Monette M. Soquiat, and Ma. Lourdes Balita. (2020). A TRACER STUDY OF BATANGAS STATE UNIVERSITY (BATSTATEU)- LIPA CITY GRADUATES OF SY 2017 - 2018. International Journal of Research GRANTHAALAYAH, 8(6), 36-42. https://doi.org/10.29121/granthaa layah.v8.i6.2020.396

Received Date: 02 May 2020

Accepted Date: 22 June 2020

Keywords:

Tracer Study

Employability

Alumni Directory

Employment Status

\section{ABSTRACT}

This study aimed to determine the employability of Batangas State University-Lipa City graduates within two (2) years after graduation. In this tracer study the BatStateU-Lipa City graduates of School Year 2017 2018 are the participants. To obtain the needed information, the researchers used online survey to be filled in by the graduates. The survey questionnaire served as the data gathering instrument. The subjects of the study were 454 graduates whose names were drawn randomly from the master list of 514 graduates of the four colleges offering different academic programs.

Findings of the study revealed that almost all of the BatStateU-Lipa City graduates are currently employed and working in a full time basis. On the other hand, more than half are holding permanent position. However, most of them are not yet pursuing masters' degree or post graduate studies. The developed alumni directory will help the University in tracking the alumni and to easily collect and update the personal and professional information of graduates.

It is recommended that the graduates may pursue professional development and advancement by taking masters' degree or advance study for them to upgrade their core competencies and land in a job that will provide vast opportunities to practice their profession. The expansion of tie-ups with public and private agencies and enterprises that can provide employment opportunities to the University graduates be a continuing process in all colleges to maintain the higher rate of employability. Further study may be conducted focusing on the relevance and responsiveness of the different programs.

\section{INTRODUCTION}

Universities play an important role in preparing graduates for today's global employment market. Thus, ensuring that students are well-equipped for post graduate work, in their chosen field, is a key aspect of higher education.

Employability is one of the many indicators included in any national and international quality survey assessment in Higher Education Institutions (HEIs). It is because employability is central to the life goals of most prospective students. Providing quality services to students with the support and connections they need to build their employability surely improve their chances of relevant and timely work after graduation.

(C) 2020 The Author(s). This is an open access article distributed under the terms of the Creative Commons Attribution License, which permits unrestricted use, distribution, and reproduction in any medium, provided the original author and source are credited. 
Employability is defined as "a set of skills, knowledge and personal attributes that make an individual more likely to secure and be successful in their chosen occupation for their own benefit, the workforce, the community and the economy" (Moreland, 2006) [1]. In securing a job, a graduate must be equipped with most of the skills desired by the employer and the ability to participate and contribute to the knowledge economy by applying what they learned in higher education and also improve their social standing and the country's economy (Paadi, 2014) [2]. One of the major concerns of higher education institutions today is connecting education and employability. Nevertheless, it must be noted that employability is the product of a complex mixture of different factors located in the labor market, in universities, in the recruitment procedures of businesses, in the economic policies implemented by the government and in the personal/social characteristics of individual graduates (Smetherham, 2003) [3].

Batangas State University -Lipa City is one of the providers of quality higher education in CALABARZON and to attain its vision of being a premier national university that develops leaders in the global knowledge economy, it offers programs which provide students the necessary technical and social skills needed by the industry for them to be well-prepared to face the challenges of their profession. According to Yorke (2001) [4] and Knight and Yorke (2002) [5] as cited by Lees (2002), employability has two main concepts, and these are the acquisition of the graduates of the necessary knowledge and skills to be employed and their ability to get a job. Also, the graduates' knowledge and skills must match the employers' expectation. One of the most common and probably the most effective way to determine the status of graduates and the relationship of their educational training with their employment status is the conduct of graduate tracer studies.

The ability for graduates to find or create work after higher education is a critical component of a university's reputation and ranking, and a key deciding factor in a student's decision-making process. Moreover, focusing on employability helps universities to attract and retain high quality students and maintain a competitive advantage in the global market.

Considering this importance, it is imperative that every university take an active role in developing their graduates' employability, hence the conceptualization of this endeavor. This paper primarily aims to determine the profile of the graduates of BatStateU- Lipa City within two (2) years after graduations in terms of status of employment, status of appointment, types of employment and the education history. At the end of the study an alumni directory is developed.

\section{OBJECTIVES}

This study was conducted to determine the employability of Batangas State University-Lipa City graduates within two (2) years after graduations. It covered the graduates from 2017-2018.

Specifically, the study aimed to attain the following objectives:

1) Determine the employment history of graduates in terms of:

- status of employment;

- status of appointment; and

- types of employment.

2) Determine the education history of graduates.

3) Develop Alumni Directory for BatStateU-Lipa.

\section{METHODOLOGY}

This paper is descriptive-survey in design since it presents a picture of the accumulated 454 responses from the BatStateU- Lipa City graduates of the four Colleges namely: College of Engineering and Computing Sciences, College of Arts and Sciences, College of Accountancy, Business and Economics from SY 2017-2018. The data was gathered primarily through online correspondence. Few of these alumni were also interviewed personally and through phone calls when they did not feel like answering the form on their own. The data gathered were statistically treated using frequency counting and percentage.

The sample size was 454, proportionately divided from the college sample size. It is calculated using Cochran with acceptable margin of error of 3 percent and 95 percent confidence level. The participants were randomly selected from the master list using random number generator. Table 1 presents the distribution of respondents per program. 
A Tracer Study of Batangas State University (Batstateu)- Lipa City Graduates of Sy 2017 - 2018

Table 1: Distribution of Respondents

\begin{tabular}{|l|c|c|}
\hline Program & Total Graduate & Sample Size \\
\hline College of Engineering and Computing Sciences (CECS) \\
\hline Bachelor of Science in Industrial Engineering & 55 & 50 \\
\hline Bachelor of Science in Computer Science & 58 & 52 \\
\hline College of Arts and Sciences (CAS) & 49 & 43 \\
\hline Bachelor of Arts in Communication & 90 & 80 \\
\hline Bachelor of Science in Psychology & 74 & 63 \\
\hline College of Accountancy, Business and Economics (CABE) & 100 \\
\hline Bachelor of Science in Accounting Management & 118 & 36 \\
\hline Bachelor of Science in Business Administration & \multicolumn{2}{|l}{} \\
\hline College of Industrial Technology & 38 & 30 \\
\hline Computer Technology & 32 & 454 \\
\hline Electrical Technology & 514 & \\
\hline TOTAL &
\end{tabular}

\section{RESULTS AND DISCUSSIONS}

\subsection{EMPLOYMENT HISTORY}

Employability is a word that can be used in different contexts and with different meanings. As it relates to higher education it means a set of achievements like skills, personal attributes that makes graduates more likely to gain employment and be successful in their chosen occupations, which benefits themselves, the workforce, the community and the economy. Information about graduates' status of employment, status of appointment and types of employment are considered in this study and these are presented in Tables 2-4.

\subsubsection{STATUS OF EMPLOYMENT}

Every university or college helps graduates to seek employment and career opportunities after graduation. Graduates' employment status is one of the major factors influencing the quality of work. Table 2 presents the status employment of graduates within two years of graduation.

Table 2: Status of Employment

\begin{tabular}{|l|c|c|c|c|c|c|c|c|c|c|}
\hline \multirow{2}{*}{ Position } & \multicolumn{2}{|c|}{ CECS } & \multicolumn{2}{c|}{ CAS } & \multicolumn{2}{c|}{ CABE } & \multicolumn{2}{|c|}{ CIT } & \multirow{2}{*}{ Total } & \multirow{2}{*}{$\%$} \\
\cline { 2 - 11 } & $\mathrm{F}$ & $\%$ & $\mathrm{~F}$ & $\%$ & $\mathrm{~F}$ & $\%$ & $\mathrm{~F}$ & $\%$ & & \\
\hline Employed & 99 & 97.06 & 121 & 98.37 & 162 & 99.39 & 62 & 93.94 & 444 & 97.78 \\
\hline Not Employed & 3 & 2.94 & 2 & 1.63 & 1 & 0.61 & 4 & 6.06 & 10 & 8.81 \\
\hline Total & 102 & 100 & 123 & 100 & 163 & 100 & 66 & 100 & 454 & 100 \\
\hline
\end{tabular}

As shown in the table, out of 454 respondents, 444 or 97.78 percent of them are currently employed and only 10 or 8.81 percent are unemployed. It is good to note that the four colleges namely: College of Engineering and Computing Sciences (CECS, College of arts and Sciences (CAS), College of Accountancy Business and Economics (CABE) and College of Industrial Technology (CIT) got 94 percent and above employability rate of graduates. The data clearly indicates that the graduates of BatStateU- Lipa City are highly employable. This also proves that the different programs/courses of the campus offer diverse and vast job opportunities. The very low unemployment rate concludes that the graduates possess the necessary skills, knowledge and personal attributes required the by the labor market which may help them to be successful in their chosen field.

This finding supports the statement given by the Center on Education Policy (2013) [6] that employability is seen as a necessary tool to succeed in entry-level employment, and often referred to as "soft skills". It can be viewed from this statement that employability is also a complete set of important skills and attributes instilled in an 
individual to enable him perform his duties well and eventually become a productive workforce. Moreover, this finding contradicts the finding of Mendoza and Valenzuela (2012) [7] in their study which revealed high unemployment rate due to skills mismatch, low level of academe qualification and job specific skills of graduates.

\subsubsection{STATUS OF APPOINTMENT}

Appointment status describes the status the employee holds in a specific position or assignment. It is made to a position which the industry has the intention of continuing on a regular basis for 6 or more months. In giving appointment the workers' skills, abilities and attitudes are being considered by employers. The graduates' appointment status is presented in Table 3.

Table 3: Status of Appointment

\begin{tabular}{|l|c|c|c|c|c|c|c|c|c|c|}
\hline \multirow{2}{*}{ Position } & \multicolumn{2}{|c|}{ CECS } & \multicolumn{2}{c|}{ CAS } & \multicolumn{2}{c|}{ CABE } & \multicolumn{2}{|c|}{ CIT } & \multirow{2}{*}{ Total } & \multirow{2}{*}{$\%$} \\
\cline { 2 - 12 } & $\mathrm{F}$ & $\%$ & $\mathrm{~F}$ & $\%$ & $\mathrm{~F}$ & $\%$ & $\mathrm{~F}$ & $\%$ & & \\
\hline Permanent & 78 & 78.78 & 86 & 71.07 & 127 & 77.91 & 38 & 57.57 & 329 & 74.10 \\
\hline Temporary & 4 & 4.04 & 10 & 8.26 & 5 & 3.07 & 3 & 4.54 & 22 & 4.96 \\
\hline Contractual & 10 & 10.10 & 9 & 7.44 & 13 & 7.98 & 8 & 12.12 & 40 & 9.01 \\
\hline Casual & 3 & 3.03 & 5 & 4.13 & 7 & 4.29 & 3 & 4.54 & 18 & 4.05 \\
\hline Job Order & 0 & 0 & 9 & 7.44 & 6 & 3.68 & 5 & 7.57 & 20 & 4.50 \\
\hline Self-employed & 4 & 3.92 & 2 & 1.65 & 4 & 2.45 & 5 & 7.57 & 15 & 3.38 \\
\hline Total & 99 & 100 & 121 & 100 & 162 & 100 & 62 & 100 & 444 & 100 \\
\hline
\end{tabular}

Relative to the appointment status of 444 employed graduates, it can be seen in the table that 329 or 74.10 percent are having permanent status and only 40 or 9.01 percent are in contractual basis. It can also be noted that the graduates in temporary, casual and self- employed status are more or less 4 percent only. It is worthy to note that almost half of the graduates of BatStateU-Lipa are already having permanent position and already enjoying security of tenure in the industries where they are presently employed though its only two years after their graduation. This further indicates that the graduates are qualified and competent in doing their job and they meet the employers' expectation in terms of their skills and competencies, which the university provides, that is why they are given permanent position. As cited by Tholen (2014) [8] employability skills have become of a great importance to the university graduates considering the recent competition in the labour market.

\subsubsection{TYPES OF EMPLOYMENT}

There are different types of employment in the Philippines and they are determined by the nature and/or existence of activities that an employee is required to perform. The employer establishes the terms and conditions of the employment contract, which should be structured according to the legal provisions, set by Philippine labor laws and regulations. Table 4 presents the types of employment of graduates on their present job.

Table 4: Types of Employment

\begin{tabular}{|l|c|c|c|c|c|c|c|c|c|c|c|}
\hline \multirow{2}{*}{ Status } & \multicolumn{2}{|c|}{ CECS } & \multicolumn{2}{c|}{ CAS } & \multicolumn{2}{c|}{ CABE } & \multicolumn{2}{c|}{ CIT } & \multirow{2}{*}{ Total } \\
\cline { 2 - 10 } & $\mathrm{F}$ & $\%$ & $\mathrm{~F}$ & $\%$ & $\mathrm{~F}$ & $\%$ & $\mathrm{f}$ & $\%$ & & \\
\cline { 1 - 10 } $\begin{array}{l}\text { Full Time (Working at least 35 hours per } \\
\text { week) }\end{array}$ & 98 & 96.08 & 112 & 91.06 & 163 & 100 & 60 & 90.90 & 433 & 95.38 \\
\hline $\begin{array}{l}\text { Part Time (Working fewer than 35 hours } \\
\text { per week }\end{array}$ & 0 & 0 & 7 & 5.69 & 0 & 0 & 2 & 3.03 & 9 & 1.98 \\
\hline Seeking Employment & 3 & 2.94 & 4 & 3.25 & 0 & 0 & 4 & 6.06 & 11 & 2.42 \\
\hline $\begin{array}{l}\text { Not available for work for reasons such as } \\
\text { ill, health, military service, travel }\end{array}$ & 1 & 0.98 & 0 & 0 & 0 & 0 & 0 & 0 & 1 & 0.22 \\
\hline Total & 102 & 100 & 123 & 100 & 163 & 100 & 66 & 100 & 454 & 100 \\
\hline
\end{tabular}


As revealed in the table, 433 or 95.38 percent out of the total respondents are working in a full time basis and only nine or 1.98 percent of graduates are part time. This finding revealed that most of the respondents exerted efforts to look for sources of income or job immediately after graduation and it could be because they believed that having work experience, especially in a job related to their field can help them become more competitive in the work market. This finding is in contract with the finding of the study conducted by Maslen (2019) [9] which found out that only $73 \%$ of recent graduates are in full-time employment.

\subsection{EDUCATION HISTORY}

Tracing the professional achievements of graduates is one of most common ways to self-initiated University's self-evaluation scheme to determine adequacy, relevance and alignment of its curricular offerings to the national and international standards for better human resource of the country. Table 5 presents the degree completed by graduates after 2 years.

Table 5: Recent Degree Completed

\begin{tabular}{|l|c|c|}
\hline Degree Completed & Frequency & Percentage (\%) \\
\hline BS Computer Science & 52 & 11.45 \\
\hline BS Industrial Engineering & 50 & 11.03 \\
\hline Bachelor of Arts in Communication & 43 & 9.47 \\
\hline Bachelor of Science in Psychology & 80 & 17.62 \\
\hline Bachelor of Science in Accounting Management & 63 & 13.88 \\
\hline $\begin{array}{l}\text { Bachelor of Science in Business Administration major in Human Resource } \\
\text { Development Management }\end{array}$ & 38 & 8.37 \\
\hline Bachelor of Science in Business Administration major in Marketing Management & 61 & 13.44 \\
\hline Masters' in Business Administration & 1 & 0.22 \\
\hline Computer Technology & 36 & 7.93 \\
\hline Electrical Technology & 30 & 6.61 \\
\hline Total & 454 & 100 \\
\hline
\end{tabular}

It was observed from the table that almost all of the respondents are still not pursuing masters' degree or other post graduates degree and only one pursue Masters' Degree. Majority of the graduates are still Bachelors' Degree holder. This is expected since it is only been two years after their graduation. This further infers that graduates prioritized their present job rather than pursuing higher degree.

However, it can be deduced from the findings that the university must exerts effort to encourage graduates in pursuing higher degree since it has been noticed that employers are faced with an uncertain future marked by rapid and continuous technological change and ageing workforce. They ought to seek for graduates who are flexible and adaptable, who demonstrate lifelong learning and have strong capacity for problem solving. Thus, graduates should pursue graduate study. Research has proven that academic qualifications are merely the 'first tick in the box' (Brown 2002) [10] and it is graduates who exhibit attainment beyond the degree that employers look for (Hugh-Jones 2008) [11].

\subsection{DEVELOPED ALUMNI DIRECTORY FOR BATSTATEU-LIPA}

With an increasing number of graduates every year in BatStateU-Lipa City, the campus struggles to collect personal and professional information from alumni. To address this problem, an online Alumni Directory is developed for tracking alumni information per program. The Directory will ultimately help the administrators to easily gather data and information regarding their graduates. These data will help improve career preparation, placement and success of their graduates.

This is one of the best strategies in tracking alumni in order to easily collect and update the personal and professional information of graduates yearly. Included in the directory are: name of graduates per program, contact 
number, home address, email address, company name, status of employment, status and type of appointment and education history.

\section{CONCLUSIONS}

Based on the findings of the study, almost all of the BatStateU-Lipa City graduates during the SY 2017-2018 are currently employed and working in a full time basis. On the other hand, more than half are holding permanent position. However, most of the graduates are not yet pursuing masters' degree or post graduate studies. The developed alumni directory will help the University in tracking the alumni and to easily collect and update the personal and professional information of graduates.

\section{RECOMMENDATIONS}

The researchers highly recommend that the graduates may pursue professional development and advancement by taking masters' degree or advance study for them to upgrade their core competencies and land in a job that will provide vast opportunities to practice the profession. The expansion of tie-ups with public and private agencies and enterprises that can provide employment opportunities to the University graduates be a continuing process in all colleges to maintain the higher rate of employability. Further study may be conducted focusing on the relevance and responsiveness of the different programs for more productive and worthy graduates.

\section{SOURCES OF FUNDING}

None.

\section{CONFLICT OF INTEREST}

None.

\section{ACKNOWLEDGMENT}

None.

\section{REFERENCES}

[1] Moreland, N. (2006). Entrepreneurship and Higher Education: An Employee Perspective. ESECT, York, Learning and employability Series.

[2] Paadi, Kelebogile (2014). Perceptions on Employability Skills Necessary to Enhance Human Resource Management Graduates Prospects of Securing a Relevant Place in the Labor Market. European Scientific Journal August 2014 /SPECIAL/edition/e - ISSN1857- 7431.

[3] Smetherham, C., (2003) (Forthcoming) 'First Class Women in the World of Work: Employability and Labour Market Orientations', Working Paper, Cardiff University School of Social Sciences

[4] Yorke, M. (2001). Assessment Issues Arising from Subject Benchmarking Statements. York: Learning and Teaching Support Network.

[5] Yorke, M. \& Knight, P. (2002). Self-theories: Some Implications for Teaching and Learning in Higher Education.

[6] Centre for Education Policy 2013, Career Readiness Assessments across States: A Summary of Survey Findings. New York: CEP.

[7] Valenzuela, Ethel Agnes P. and Mendoza, Elaisa Marina E. (2012). Employability of Graduates in the Philippines. Asia pacific Regional Bureau for Education. UNESCO Bangkok

[8] Tholen, G 2014, Graduate Employability and Educational Context: A Comparison between Great Britain and the Netherlands. British Educational Research Journal, Vol. 40, No. 1, February 2014, pp. 1-17 DOI: 10.1002/berj.3023 
A Tracer Study of Batangas State University (Batstateu)- Lipa City Graduates of Sy 2017 - 2018

[9] Maslen, Geoff (2019). International Higher Education, Special Issue \# 102, 2020. Retrieved at https://www.universityworldnews.com/post.php?story=20191030133222445

[10] Brown, P, Hesketh, A \& Williams, S 2002, Employability in a Knowledge-driven Economy. In Knight, P. (compiler) Notes from the 13th June 2002 'Skills plus' conference, Innovation in Education for Employability held at Manchester Metropolitan University

[11] Hugh-Jones, S 2008, The Graduate - Are We Giving Employers What They Want? The Psychologist. 21, 12, 1050-1051. 